No 4069

Studia nad Autorytaryzmem i Totalitaryzmem 43, nr 2

Wrocław 2021

https://doi.org/10.19195/2300-7249.43.2.29

PIOTR LISOWSKI

ORCID: 0000-0002-8154-3167

Uniwersytet Wrocławski

piotr.lisowski@uwr.edu.pl

\title{
Nihil novi? Czyli o antecedencjach sądowej ochrony autonomii administracyjnej uczelni publicznej w Polsce
}

Słowa kluczowe: autonomia administracyjna, uczelnie publiczne, sądowa ochrona.

\section{NIHIL NOVI? ON THE ANTECEDENTS OF THE JUDICIAL PROTECTION OF THE AD- MINISTRATIVE AUTONOMY OF A PUBLIC UNIVERSITY IN POLAND}

\begin{abstract}
Administrative autonomy, which is the most advanced type of decentralising public administration, plays a key role in robustly safeguarding academic freedom. In the over a century-long history of the practice of the Polish regulations pertaining to the organisation and functioning of public universities, no principle of the judicial protection of the higher education institutions' independence has been formulated - not even under the regulations of article 70 (5) of the Constitution of the Republic of Poland. This legislative negligence poses serious threats in the current legal situation, which only worsens in the environment that facilitates the authoritarian activities of public authorities in Poland.
\end{abstract}

Keywords: administrative autonomy, public universities, judicial protection. 


\section{Ratio sausoria - deficyt normatywny czy przezroczysty aksjomat prawa ustrojowego}

W żadnym z polskich źródeł powszechnie obowiązującego prawa regulujących — na przestrzeni ponad stu ostatnich lat ${ }^{1}-\mathrm{w}$ formule przepisów typu lex generalis $^{2}$ problematykę szkół wyższych, nie wprowadzono zasady sądowej ochrony ich samodzielności. To zaskakujące ustalenie, jeżeli wziąć pod uwagę atrybuty i potrzeby autonomii uczelni - szczególnie zastanawiające począwszy od dnia 17 października 1997 roku, to jest pod rządami konstytucyjnie już gwarantowanej autonomii szkół wyższych ${ }^{3}$ (a więc w stosunku do: u.sz.w.1990, P.sz.w. i P.sz.w.n.). Co ciekawe, takiej klauzuli nie wprowadza też żadne z 16 źródeł prawa, do których odsyłają przepisy art. 25 ust. 4-5 Konstytucji RP, ani ustawa z dnia 17 maja 1989 roku o gwarancjach wolności sumienia i wyznania ${ }^{4}$. O ile jednak w odniesieniu do 15 kościołów i innych związków wyznaniowych niewprowadzenie tego rodzaju gwarancji można uznać za niewywołujące istotnych konsekwencji ${ }^{5}$, to w kontekście uczelni nie jest to już tak bezpieczna konstatacja. Przede wszystkim w kontekście systemowym, wobec konstatowanych już zmian, których skutki nie bez przyczyny określa się mianem „konwulsji państwa

${ }^{1}$ Ustawa z dnia 20 lipca 2018 roku — Prawo o szkolnictwie wyższym i nauce (Dz.U. z 2021 r. poz. 478 ze zm.; dalej: P.sz.w.n.) jest dziewiątym z kolei aktem normatywnym o takim przeznaczeniu. Wcześniej obowiązywały: ustawa z dnia 13 lipca 1920 roku o szkołach akademickich (Dz.U. z 1920 r. Nr 72, poz. 494 ze zm.; dalej: u.sz.a.1920); ustawa z dnia 15 marca 1933 roku o szkołach akademickich (Dz.U. z 1938 r. Nr 1, poz. 6 ze zm.; dalej: u.sz.a.1933); dekret z dnia 28 października 1947 roku o organizacji nauki i szkolnictwa wyższego (Dz.U. z 1947 r. Nr 66, poz. 415 ze zm.; dalej: dekret z 1947 roku); ustawa z dnia 15 grudnia 1951 roku o szkolnictwie wyższym i pracownikach nauki (Dz.U. z 1956 r. Nr 45, poz. 205 ze zm.; dalej: u.sz.w.p.n.); ustawa z dnia 5 listopada 1958 roku o szkolnictwie wyższym (Dz.U. z 1973 r. Nr 32, poz. 191 ze zm.; dalej: u.sz.w.1958); ustawa z dnia 4 maja 1982 roku o szkolnictwie wyższym (Dz.U. z 1985 r. Nr 9, poz. 191 ze zm.; dalej: u.sz.w.1982); ustawa z dnia 12 września 1990 roku o szkolnictwie wyższym (Dz.U. z 1990 r. Nr 65, poz. 395 ze zm.; dalej: u.sz.w.1990); ustawa z dnia 27 lipca 2005 roku — Prawo o szkolnictwie wyższym (Dz.U. z 2017 r. poz. 2183 ze zm.; dalej: P.sz.w.).

2 Analiza nie obejmuje ustaw dotyczących wyodrębnionych typów szkół wyższych. Charakter opracowania przesądza także o skupieniu uwagi na polskich doświadczeniach w normatywizacji tej materii, ograniczonych do - stosując aktualną nomenklaturę - uczelni publicznych.

3 Art. 70 ust. 5 Konstytucji Rzeczypospolitej Polskiej z dnia 2 kwietnia1997 roku (Dz.U. z 1997 r. Nr 78, poz. 483 ze zm.; dalej: Konstytucja RP). Notabene ustrojodawca po raz pierwszy wprowadził takie zastrzeżenie, zob. P. Lisowski, Fenomen autonomii uczelni jako aksjomat administracji publicznej (prawa administracyjnego), [w:] Fenomen prawa administracyjnego. Ksiega Jubileuszowa Profesora Jana Zimmermanna, red. W. Jakimowicz, M. Krawczyk, I. Niżnik-Dobosz, Warszawa 2019, s. 586, 578 (przypis 10).

${ }^{4}$ Dz.U. z 2017 r. poz. 1153 ze zm.

${ }^{5}$ Ustrojodawca różnicuje bowiem podejście do autonomii na korzyść podmiotów konfesyjnych, wyraźniej gwarantując filary ich autonomii (P. Lisowski, Fenomen autonomii uczelni..., s. 584-585). 
prawa"6. Poza tym aktualny stan normatywizacji autonomii administracyjnej szkół wyższych prowokuje zagrożenia dla sytuacji ustrojowej szkół wyższych ${ }^{7}$.

Możliwość zaskarżania aktów nadzoru dotyczących szkół wyższych nie wynika więc z systemowego przyzwolenia, jak dotychczas, dawkowana jest bowiem punktowo, legitymując się przedmiotowo motywowanym uzasadnieniem. Zatem to typ formy działania administracji i związana $\mathrm{z}$ nim normatywna dekretacja przesądzają o dopuszczalności poddawania ingerencji nadzorczej bezpośredniej kontroli sądowej. Nie jest to więc efekt uzasadnień o stricte podmiotowej proweniencji - nie ma więc też mowy o wprowadzaniu tak motywowanej klauzuli generalnej (jak w przypadku jednostek samorządu terytorialnego) ${ }^{8}$.

Tego rodzaju wymagań explicite nie inspirują też postanowienia Magna Charta Universitatum ${ }^{9}$, dość aksjomatycznie i wybiórczo traktujące kontekst autonomicznych atrybutów uczelni, w dodatku skupiające uwagę na wolności akademickiej (a więc autonomii odnoszonej do działalności podstawowej uczelni) ${ }^{10}$. Tymczasem równie istotna, by nie rzec - podstawowa, jest autonomia administracyjna ${ }^{11}$, stanowiąca najbardziej zaawansowaną formę decentralizacji administracji publicznej ${ }^{12}$. To w jej gestii pozostaje bowiem prawne dookreślanie zasad organizacji i funkcjonowania poszczególnych szkół wyższych. Trudno nie doceniać praktycznego i docelowego kontekstu, wymiaru oraz znaczenia tej właśnie - ujawniającej się w płaszczyźnie ściśle prawno-pozytywnej — odmiany decentralizacji autonomicznej. Bezsporne jest przecież, że ,autonomia szkół wyższych ma na celu stworzenie tym instytucjom warunków do optymalnej realizacji ich zadań w zakresie prowadzenia badań naukowych i nauczania"13.

${ }^{6}$ E. Łętowska, Państwo prawa na peryferiach Europy, https://publica.pl/teksty/letowska-panstwo-prawa-na-peryferiach-europy-61676.html (dostęp: 16.02.2021); wystąpienie prof. Ewy Łętowskiej z okazji przyznania nagrody Democracy \& Diversity Institute przyznawanej przez New School for Social Research Europe Collective.

${ }^{7}$ P. Lisowski, Fenomen autonomii uczelni..., s. 586-587, 589-591.

${ }^{8}$ Notabene Konstytucja RP — podobnie jak jej poprzedniczki — również nie wprowadza tak motywowanej gwarancji systemowej (Konstytucje Rzeczypospolitej oraz komentarz do Konstytucji $R P$ z 1997 r., red. J. Boć, Wrocław 1998, s. 128-130).

${ }^{9}$ Dalej: Karta.

10 Zd. pierwsze i drugie pkt 1 oraz 3 podstawowych zasad Karty.

11 Zwana też instytucjonalną — na przykład A. Budnik, A. Miruć, Autonomia szkół wyższych w świetle przepisów ustawy - Prawo o szkolnictwie wyższym, [w:] Kryzys prawa administracyjnego? Inflacja prawa administracyjnego, t. 2, red. P.J. Suwaj, Warszawa 2012, s. 207-208. Tam też wskazano na potrzebę delimitowania wspomnianego wymiaru autonomii szkół wyższych względem autonomii (swobody) akademickiej. Tę sui generis dyletację terminologiczno-pojęciową eksponuje obecnie treść art. 3 ust. 2 P.sz.w.n.

12 W kwestii odróżniania autonomii administracyjnej od ustawodawczej — na przykład P. Lisowski, Zróżnicowanie samorządu terytorialnego a unitarność, [w:] Unitarny charakter państwa a samorzą terytorialny, red. M. Stec, K. Małysa-Sulińska, Warszawa 2019, s. 215-216.

13 M. Masternak-Kubiak, Autonomia szkót wyższych na gruncie Konstytucji RP, [w:] Nowe prawo o szkolnictwie wyższym a podmiotowość studenta, red. A. Szadok-Bratuń, Wrocław 2007, s. 17. 
O ile jednak — summa summarum — nie dziwi brak definicji legalnej autonomii (także administracyjnej) ${ }^{14}$, to zastanawia, a obecnie wręcz niepokoi ${ }^{15}$, dotychczasowe podejście do kwestii sądowej ochrony samodzielności autonomicznych szkół wyższych. Wobec doświadczanego w Polsce kryzysu standardów demokratycznego państwa prawnego warto więc postawić pytanie o to, czy taki stan prawny należy kwalifikować jako zaniechanie prawodawcze czy tylko wyraz optymistycznego podejścia ustawodawcy do potrzeb autonomii administracyjnej uczelni (sprowadzający wątek sądowego jej asekurowania do rangi przezroczystego aksjomatu), niegrożący brzemiennymi w skutkach konsekwencjami?

Bezspornie aktualne zaliczanie ${ }^{16}$ do materii ustawowej zasady autonomii administracyjnej szkół wyższych ${ }^{17}$, a potem jej dookreślanie w ramach autonomicznego prawa zakładowego oraz praktyki wykonywania prawa ustrojowego szkół wyższych - istotnie warunkują praktyczny wymiar „wolności nauczania, twórczości artystycznej, badań naukowych i ogłaszania ich wyników” (art. 3 ust. 1 P.sz.w.n.). Niewątpliwie stanowią ważne filary wyznaczające swego rodzaju pole siłowe chroniące funkcjonowanie uczelni przed nadmiernymi, zewnętrznie inspirowanymi akcesami kontrolno-nadzorczymi. W tym zakresie trudno natomiast przecenić znaczenie regulacji prawnych wyznaczających zasady i tryb nadzorowania uczelni. Faktem notoryjnym jest przecież, że swoistym rewersem przepisów skupionych na normowaniu nadzoru są — w kontekście tego rodzaju sposobów oddziaływania w ramach relacji strukturalnych ${ }^{18}$ — przepisy o sądowej kontroli aktów nadzoru. Takowe w tym względzie występują, problem jednak w tym, że są „dawkowane”, w dodatku w stosunku do podmiotów administracji publicznej korzystających z ustrojowego przyzwolenia do funkcjonowania w ramach najwyższego stopnia decentralizacji administracyjnej. Co zaś szczególnie istotne, hic et nunc owo „dawkowanie” dotyczy praktyki administracyjnej poddawanej coraz wyraźniejszym wpływom ,autorytarnych pokus” władzy publicznej.

14 „Przesądza o tym eteryczna natura autonomii, wymagająca niekazuistycznych identyfikacji. Mamy bowiem do czynienia ze zjawiskiem obiektywnie trudno uchwytnym, którego - niejako ex defintione - nie należy wyczerpująco normatywizować. Kluczowe założenie konstrukcyjne sprowadza się przecież w tym przypadku do kreowania podmiotu administracji publicznej o ustrojowo motywowanej swobodzie funkcjonowania, której właściwości inklinują bardziej do atrybutów typu niezależność niż samodzielność. Sprzyjają temu silne konotacje do konstruowania sytuacji ustrojowych takich podmiotów bardziej w formule »wolności od « niż »prawa do«" — P. Lisowski, Fenomen autonomii uczelni..., s. 581-582.

15 Zważywszy na nasilające się od jesieni 2015 roku autorytarne inklinacje w funkcjonowaniu wielu instytucji publicznych w Polsce, w tym ministra sprawującego nadzór nad uczelniami publicznymi - czego szczególnym wyrazem jest zarówno tryb wydania, jak i treść komunikatu Ministra Edukacji i Nauki z dnia 9 lutego 2021 roku w sprawie wykazu czasopism naukowych i recenzowanych materiałów z konferencji międzynarodowych.

16 Analiza historyczna wykaże, że eksponowanie autonomii administracyjnej szkół wyższych cieszy się relatywnie niedługim stażem ustawodawczym.

17 Art. 70 ust. 5 Konstytucji RP, w zw. z art. 9 ust. 2 P.sz.w.n.

$18 \mathrm{Na}$ temat tego rodzaju terminologiczno-pojęciowych antecedencji - P. Lisowski, Relacje strukturalne w polskim samorządzie terytorialnym, Wrocław 2013, s. 31, 117-171. 


\section{Autonomia administracyjna uczelni publicznych - refleksje systemowe w perspektywie historycznej}

Retrospektywa ograniczona do początków II RP potwierdza, że stopień uwzględniania autonomicznych potrzeb szkół wyższych, dywersyfikacji płaszczyzn ich ujawniania i eksponowania takich kontekstów nieustająco ewoluuje. Warto zatem w zakreślonej powyżej perspektywie historycznej spojrzeć na uwarunkowania problematyki sądowej ochrony autonomii uczelni publicznych.

Dopiero pod rządami siódmej z kolei regulacji — to jest u.sz.w.1990 — zdecydowano się na monograficzne normatywizowanie materii nadzoru nad szkołami ${ }_{\text {wyższymi }}{ }^{19}$, utrzymując ten trend w kolejnych ustawach: P.sz.w. i P.sz.w.n. ${ }^{20}$ Nie zawsze jednak tego rodzaju zabiegi legislacyjne prowadziły do wyczerpującego uregulowania w takim rozdziale problematyki nadzoru nad uczelniami publicznymi ${ }^{21}$.

Zdecydowanie dłuższym wsparciem normatywnym legitymuje się sfera wolności akademickiej. Już bowiem w art. 6 u.sz.a.1920 zastrzeżono, że

Szkołom akademickim przysługuje prawo wolności nauki i nauczania. Każdy profesor i docent szkoły akademickiej ma prawo podawać i oświetlać z katedry według swego naukowego przekonania i sposobem naukowym wszelkie zagadnienia, wchodzące w zakres gałęzi wiedzy, których jest przedstawicielem; tak samo ma zupełną swobodę w wyborze metod wykładów i ćwiczeń.

Równie wyraźnie, acz w sposób bardziej stonowany, uregulowano tę kwestię w u.sz.w. $1933^{22}$.

Z kolei w dekrecie z 1947 roku — co, zważywszy na ówczesne uwarunkowania, nie dziwi — ograniczono się w tym zakresie do następującego zastrzeżenia: „Badania naukowe są wolne” (art. 1 ust. 1). Również nie zaskakuje pominięcie tego rodzaju aspektów w u.sz.w.p.n. Bezspornie w 1951 roku trudno było przecież o normatywną akceptację dla takich konotacji. Dlatego zauważeniu materii prowadzenia badan naukowych (art. 1 pkt 2-4) nie towarzyszyło eksponowanie atrybutów wolności akademickiej ${ }^{23}$. Podejście do tej kwestii nie zmieniło się pod rządami u.sz.w.1958.

Paradoksalnie - zważywszy na fakt, że kolejną (szóstą) ustawę uchwalono w stanie wojennym — pewne nawiązania do atrybutów wolności akademickiej

19 Rozdział 1 w dziale II (odpowiednio: Nadzór nad uczelniami państwowymi, Nadzór nad uczelniami i przedstawicielstwo szkolnictwa wyższego).

20 Szczegóły w następnym punkcie.

21 Zob. na przykład w P.sz.w.: art. 11a ust. 5, art. 11 b ust. 2-3, art. 57 ust. 1-2, art. 73 ust. 1 i 3, art. 74-75, art. 78 ust. 5-6.

22 Art. 1 ust. 1: ,Szkoły akademickie zorganizowane są na zasadzie wolności nauki i nauczania. Zadaniem ich jest prowadzenie badawczej i twórczej pracy naukowej lub artystycznej, wdrażanie do samodzielnych badań naukowych lub twórczości artystycznej [...]”.

23 Także po zmianach wprowadzonych nowelizacją z dnia 10 września 1956 roku (Dz.U. z 1956 r. Nr 41, poz. 185). 
powróciły (przynajmniej literalnie) w u.sz.w.1982. W art. 2 ust. 3 zd. pierwsze tego aktu normatywnego przesądzono bowiem o tym, że „Szkoły wyższe w swej działalności kierują się zasadami wolności nauki i sztuki”. Zarówno jednak sposób sformułowania tego przepisu (nie zagwarantowano nim przecież prawa do wolności akademickiej jako klasycznie rozumianej klauzuli generalnej — zamiast tego ograniczono się kreowania dyrektywy kierunkowej dopuszczającej „kierowanie się” nawiązaniami do wzmiankowanych w tym przepisie zasad), jak i uwarunkowania determinowane innymi przepisami tej ustawy ${ }^{24}$ sprawiały, że trudno było o realny i pełny powrót do standardów wolności akademickiej.

To stało się natomiast możliwe - wobec zmiany uwarunkowań politycznych i ustrojowych — pod rządami u.sz.w.1990. Począwszy bowiem od 27 września 1990 roku ponownie expressis verbis klasycznie i systemowo opowiedziano się za wolnością akademicką: „Szkoły wyższe, zwane dalej »uczelniami«, są organizowane i działają na zasadzie wolności badań naukowych, wolności twórczości artystycznej i wolności nauczania" (art. 2 ust. 1). Tę tendencję utrzymano w ósmym z kolei akcie normatywnym przeznaczonym do regulowania problematyki szkolnictwa wyższego, dając temu wyraz w art. 4 ust. 2 P.sz.w.: „Uczelnie kierują się zasadami wolności nauczania, badań naukowych i twórczości artystycznej”. Tym razem ponownie więc znalazła zastosowanie formuła odwołująca się (przy wyznaczaniu tego rodzaju autonomicznych atrybutów) do „kierowania się zasadami [...]”, jednak — inaczej niż w latach osiemdziesiątych XX wieku — nie obudowano tego uwarunkowaniami $\mathrm{w}$ istocie blokującymi skorzystanie $\mathrm{z}$ tak motywowanych swobód.

Pamiętając o kluczowym znaczeniu autonomii administracyjnej, wypada zauważyć, że tym zakresie również daje się dostrzec fluktuacje w sposobie normatywizowania. Co ciekawe, polski prawodawca dość długo explicite nie zajmował się tym aspektem autonomii ustrojowej szkół wyższych. Wyraźną zmianę podejścia do tej kwestii zawdzięczamy skutkom konstytucyjnego zagwarantowania autonomii uczelni. Ten impuls znalazł jednak expressis verbis potwierdzenie dopiero w P.sz.w. - a więc po prawie ośmiu latach od wejścia w życie Konstytucji RP. Wcześniej natomiast wątek autonomii administracyjnej albo nie był wprost wyrażany, albo nawet nie znajdował domyślnego zastosowania.

I tak w u.sz.a. 1920 opowiedziano się za tą formą decentralizacji autonomicznej w następujący sposób: „Ustawa niniejsza określa zasady ustroju szkół akademickich, w sposób jednolity. W granicach jej zostaje przyznany każdej z nich samorząd i możność wydawania własnego statutu, zawierającego przepisy szczegółowe i rozwijającego podane tu zasady. Przepisy te nie mogą jednak sprzeciwiać się zawartym tu postanowieniom" (art. 1 u.sz.a.1920). Akcenty autonomiczne nie zostały więc wyrażone explicite. Tego rodzaju konteksty wyraźnie stonowano w u. sz.w.1933 (zob. art. 3 ust. 3), co jeszcze pogłębiło się po II wojnie światowej (zob. art. 56 ust. $1 \mathrm{zd}$. pierwsze dekretu z 1947 roku).

${ }^{24}$ Na przykład: art. 1 ust. 1, art. 2 ust. 2 i art. 3 ust. 1-2 u.sz.w.1982. 
W kolejnych ustawach (u.sz.w.p.n. i u.sz.w.1958) analizowany kontekst stracił już literalny punkt zaczepienia. Z kolei w u.sz.w.1982 podejmowano wątek atrybutów związanych z samodzielnością szkół wyższych, jednak ówczesne uwarunkowania nie dość, że wykluczały nawiązywanie ,aż” do autonomii administracyjnej, to jeszcze nie sprzyjały realnemu wdrażaniu rozwiązań o samorządowym przeznaczeniu ${ }^{25}$.

Proces ustawowego przywracania nawiązań do ustrojowych konotacji z autonomią administracyjną nabrał tempa w ostatniej dekadzie XX wieku. Początkowo jednak jeszcze $\mathrm{w}$ dotychczasowej konwencji, akcentującej atrybuty właściwe dla perspektywy związanej z samorządnością, tyle że tym razem mające już realne szanse na realizację. W art. 6 ust. 2 u.sz.w. 1990 przesądzono bowiem o tym, że „Nauczyciele akademiccy, studenci i pracownicy uczelni nie będący nauczycielami akademickimi tworzą samorządną społeczność akademicką". Natomiast w stanie prawnym obowiązującym od 1 września 2005 roku wprost już stwierdzono, że „Uczelnia jest autonomiczna we wszystkich obszarach swojego działania na zasadach określonych w ustawie" (art. 4 ust. 1 P.sz.w.) ${ }^{26}$. Tak szeroko ustawionego zapewnienia nie utrzymano jednak w aktualnym stanie prawnym — zob. art. 9 ust. 2 P.sz.w.n. ${ }^{27}$

\section{Historyczna perspektywa przepisów dotyczących zasad i trybu nadzorowania uczelni publicznych}

Prawodawca dopiero od u.sz.w.1990 zaczął poświęcać problematyce nadzorczej osobny rozdział w ustawie. Wcześniej te zagadnienia stanowiły oczywiście przedmiot normowania, jednak najpierw w ramach ,porozrzucanych" po aktach normatywnych regulacji, a z czasem (począwszy od u.sz.w.1958, poprzez u.sz.w.1982) w warunkach narastającej tendencji do systemowego podejmowania tego rodzaju problematyki (tyle że jeszcze nie w randze rozdziału o takim przeznaczeniu). Co ciekawe, tym zagadnieniom najmniej uwagi poświęcono w u.sz.a.1920. Poza art. 1 zd. czwarte i art. 5 nie wprowadzono bowiem innych tytułów do nadzorowania ówczesnych szkół akademickich. Sprawowanie przez ministra wyznań religijnych

25 „Szkoły wyższe są samorządnymi społecznościami nauczycieli akademickich, studentów i innych pracowników szkoły” — art. 1 ust. 2; „W zarządzaniu samorządną szkołą wyższą uczestniczy cała społeczność szkoły poprzez wybieralne organy kolegialne i jednoosobowe" — art. 4 ust. 1. Tytułem przykładu wystarczy wskazać na przepisy dotyczące trybu wyboru rektora (zob. art. 41 u.sz.w.1982), a ich ewolucję trudno uznać za sprzyjającą urealnianiu samorządności akademickiej.

${ }^{26}$ Co jednak warte podkreślenia, tego rodzaju dyrektywy kierunkowej nie wspierano już przepisem ustanawiającym społeczność akademicką (na co między innymi zwrócił uwagę Z. Janku, Publiczna szkoła wyższa - korporacja czy zakład administracyjny, [w:] Między tradycja a przyszłościa w nauce prawa administracyjnego. Księga jubileuszowa dedykowana Profesorowi Janowi Bociowi, red. J. Supernat, Wrocław 2009, s. 239.

27 P. Lisowski, Fenomen autonomii uczelni..., s. 579. 
i oświecenia publicznego zwierzchniej władzy rządowej nad tymi szkołami nie polegało więc na intensywnym legitymowaniu do podejmowania aktów nadzoru (zarówno w płaszczyźnie ad meritum, jak i ad personam).

W kolejnej ustawie podejście zdecydowanie się zmieniło, doprowadzając do ustanowienia licznych podstaw prawnych do sprawowania nadzoru przez wspomnianego ministra (jako władzę naczelną szkół akademickich sprawującą nad nimi zwierzchni nadzór ${ }^{28}$, także w zakresie oddziaływania w płaszczyźnie ad personam (w stosunku do wyboru rektora i prorektora) ${ }^{29}$.

Dekret z 1947 roku jeszcze bardziej zintensyfikował tę tendencję. Punkt wyjścia do tego progresu stanowił art. 7: „Minister Oświaty jest władzą naczelną w sprawach organizacji nauki, szkół wyższych [...]. W tym zakresie sprawuje on kierownictwo naczelne oraz opiekę i zwierzchni nadzór nad instytucjami podlegającymi przepisom niniejszego dekretu". Zmiany polegały przede wszystkim na zwiększeniu nadzorczego wpływu ministra (na przykład w miejsce zatwierdzania statutu wprowadzono jego nadawanie ${ }^{30}$; zamiast zatwierdzania rektora uprzednio wybranego przez zebranie delegatów wydziałów — przez Prezydenta RP, na wniosek zwierzchniej władzy rządowej, w przypadku na przykład wyższych szkół akademickich, wprowadzono powołanie rektora przez Prezydenta RP na wniosek ministra oświaty po zasięgnięciu opinii Rady Głównej ${ }^{31}$ ).

Pogłębianiu koncentracji kompetencji w zarządzaniu szkołami wyższymi w warunkach wzmacnianej centralizacji sprzyjał moment uchwalenia kolejnej ustawy. W efekcie u.sz.w.p.n. w pierwotnym brzmieniu ${ }^{32}$ poddała szkoły wyższe jeszcze intensywniejszemu oddziaływaniu - tym razem ministra szkolnictwa wyższego. Dobrze ilustrują to przyjęte wówczas rozwiązania: utrzymaniu kompetencji ministra do nadawania statutu szkole wyższej towarzyszyło ustanowienie instytucji statutu wzorcowego; powołanie i odwołanie rektora zastrzeżono do kompetencji ministra (nie przewidując już udziału innych organów w tych procedurach ${ }^{33}$ ). $Z$ czasem jednak unormowania u.sz.w.p.n. uwzględniły efekty tak zwanej odwilży. Na mocy postanowień ustawy z dnia 10 września 1956 roku o zmianie ustawy o szkolnictwie wyższym i pracownikach nauki zrezygnowano więc z instytucji statutu wzorcowego, przesądzając zarazem o tym, że „Statut nadaje minister na wniosek senatu szkoły, przedstawiony przez rektora" (art. 5 ust. 3 u.sz.w.p.n.). Z kolei w dodanym art. 19a ust. 1 i 2 u.sz.w.p.n. zastrzeżono, że rektora wybiera senat (lub odpowiednio ukonstytuowane na forum szkoły wyższej zebranie wyborcze) ${ }^{34}$.

${ }^{28}$ Zob. art. 4 ust. 1, w zw. z (na przykład): art. 3 ust. 4, art. 5 ust. 4 i 7, art. 6 ust. 6, art. 7 ust. 2, art. 16 ust. 6 , art. 42 ust. $2-4-$ u.sz.a.1933.

29 Zob. art. 9 ust. 3-4 oraz art. 14 ust. 1 u.sz.a.1933.

30 Por. art. 3 ust. 4 u.sz.a. 1933 z art. 56 ust. 2 dekretu z 1947 roku.

31 Por. art. 9 ust. 1-4 u.sz.a. 1933 z art. 31 ust. 1 dekretu z 1947 roku.

32 Zob. Dz.U. z 1952 r. Nr 6, poz. 38.

33 Odpowiednio: art. 5 ust. 2 i 3 oraz art. 19 ust. 1 i 4 pierwotnego brzmienia u.sz.w.p.n.

${ }^{34} \mathrm{Z}$ możliwością złożenia sprzeciwu w stosunku do tego wyboru przez ministra (art. 19a ust. 5 u.sz.w.p.n.). Zarazem pozostawiono ministrowi kompetencje do odwoływania rektora, ze wskazaniem 
Pod rządami u.sz.w.1958 zapoczątkowano zaś normatywizację szerzej i wyraźniej podejmującą już problematykę kontrolno-nadzorczą. Oprócz unormowań przewidujących oddziaływanie na szkoły wyższe z pozycji — wtedy — eksponujących nastawienie na zarządzanie nimi (zob. przepisy dotyczące powoływania i odwoływania rektora, notabene - ponownie ewoluujące ${ }^{35}$ ), doszły bowiem regulacje o stricte kontrolno-nadzorczym przeznaczeniu. W pierwotnym brzmieniu tej ustawy wprowadzono następujące przepisy: „Minister [...] kontroluje działalność szkoły wyższej. Minister może żądać od organów szkoły wyższej złożenia wyjaśnień w każdej sprawie”; „Minister [...] ma prawo uchylić lub zawiesić każdą uchwałę lub decyzję organu szkoły wyższej w przypadku, gdy jest ona sprzeczna z prawem lub narusza interes publiczny"36. Docelowo wspomnianą kompetencję nadzorczą uregulowano następująco: „Minister [...] może zawiesić, uchylić lub zmienić decyzję każdego organu szkoły, naruszającą prawo lub interes społeczny; w razie uchylenia decyzji Minister określa dalszy tryb postępowania" ${ }^{37}$. W u.sz.w.1958 po raz pierwszy też wyznaczono systemową kompetencję ministra do stosowania ex post środka nadzoru ad meritum - działającego ze skutkiem ex nunc, z dewolucją kompetencji włącznie. Ówczesne uwarunkowania nie stwarzały zarazem szansy na poddawanie tego rodzaju ingerencji bezpośredniej kontroli sądowej.

Przypomnieć warto również o tym, że w art. 5 ust. 1 pkt 7 tej ustawy expressis verbis przyznano, że w ramach wykonywania zwierzchniego nadzoru nad szkołami wyższymi właściwy minister wykonuje w stosunku do tych podmiotów administracji publicznej inne czynności nadzorcze niż określone w art. 5 ust. 1 pkt 1-6, co istotne - nie tylko „określone w ustawie niniejszej”, ale i w przepisach o urzędzie tego ministra.

Kolejna ustawa (uchwalona w stanie wojennym) pierwotnie $-\mathrm{w}$ rozdziale 4 działu I pod tytułem Minister Nauki, Szkolnictwa Wyższego i Techniki — podtrzymała trend do systemowego podejmowania problematyki kontrolno-nadzorczej ${ }^{38}$. Szczególnie zaś zasługuje na przypomnienie to, że w pierwotnej wersji tekstu tej ustawy $^{39}$ zadebiutował przepis przewidujący, iż decyzje nadzorcze ministra „mogą

powodu takiej ingerencji oraz z zastrzeżeniem, że może do tego dojść na wniosek senatu lub po wysłuchaniu jego opinii (art. 19c u.sz.w.p.n.).

35 Pierwotnie bowiem pierwszeństwo w wyborze rektora zapewniono organom szkoły wyższej, odwołanie z tej funkcji pozostawiono ministrowi - zob. art. 21 i art. 24 pierwotnego brzmienia u.sz.w.1958 (Dz.U. z 1958 r. Nr 68, poz. 336). Nowelizacja uchwalona w dniu 20 grudnia 1968 roku (Dz.U. z 1968 r. Nr 46, poz. 334; inspirowana kolejnym PRL-owskim ,przesileniem”) przywróciła zaś do samodzielnej właściwości ministra powoływanie i odwoływanie rektorów (docelowo - art. 12 ust. 1 i 2 u.sz.w.1958).

36 Zob. art. 5 ust. 3 i 4.

37 Art. 5 ust. 4 u.sz.w. 1958.

38 Zob. art. 24-25 u.sz.w.1982 (w pierwotnym brzmieniu - Dz.U. z 1982 r. Nr 5, poz. 20).

39 Oprócz podtrzymania systemowego umocowania do sprawowania nadzorczego nadzoru ad meritum — do uchylania „decyzji rektora i uchwał senatu naruszających prawo” — art. 25 ust. 1 pkt 2 pierwotnego brzmienia u.sz.w.1982. 
być zaskarżane do sądu administracyjnego na zasadach i w trybie przewidzianym przez Kodeks postępowania administracyjnego" (art. 25 ust. 3 u.szw.1982 ${ }^{40}$ ). Na podobne traktowanie zasługuje też pierwotna treść art. 6 ust. 4 u.szw.1982, zaliczająca do materii ustawowej podstawy prawne do ingerencji nadzorczej: „Właściwe organy państwowe mogą podejmować decyzje dotyczące działalności szkół tylko w wypadkach przewidzianych w ustawie".

Ponownie jednak przy omawianiu tej ustawy zauważyć należy, że w trakcie jej obowiązywania ustawodawca odchodził od rozwiązań o relatywnie progresywnym nastawieniu. Na mocy ustawy z dnia 25 lipca 1985 roku o zmianie ustawy o szkolnictwie wyższym ${ }^{41}$ od dnia 12 sierpnia 1985 roku u.sz.w.1982 nie zawierała już bowiem przepisów o takim przeznaczeniu jak wzmiankowane w art. 24-25 tej ustawy (w pierwotnym ich brzmieniu) ${ }^{42}$. Nieco mniej radykalna, ale też skutkująca uszczupleniem gwarancji samodzielności szkół wyższych zmiana dotyczyła wspomnianego zastrzeżenia do materii ustawowej. We wzmiankowanym art. 6 ust. 4 zwrot „w wypadkach przewidzianych w ustawie” zastąpiono bowiem (niestety) sformułowaniem „w wypadkach przewidzianych w przepisach ustawowych”.

W nawiązaniu do wątków statutowo-rektorskich warto dodać, że uchwalenie statutu pozostawiono wówczas w gestii senatu (we współdziałaniu z organami kolegialnymi szkoły oraz działającymi w niej organizacjami politycznymi i społecznymi), wikłając zarazem tę procedurę w ewoluujące (acz zawsze silne) zależności z właściwym ministrem ${ }^{43}$. Co się zaś tyczy obsady stanowiska rektora, to jego wybór pozostawiono najpierw w gestii senatu (lub kolegium elektorów), $\mathrm{z}$ czasem był to już jednak wybór kandydatów na rektora. Poza tym pierwotnie minister mógł zablokować wybór rektora sprzeciwem, by po przeszło trzech latach uzyskać kompetencję do jego powoływania (spośród kandydatów wybranych przez senat) ${ }^{44}$.

${ }^{40} \mathrm{~W}$ pierwotnym brzmieniu tej ustawy. Notabene w art. 25 ust. 1 pkt 2 ingerencję ad meritum ex post ograniczono do uchylenia. Utrzymano też brak terminu na zastosowanie tego środka nadzorczego.

41 Dz.U. z 1985 r. Nr 36, poz. 167 (dalej: nowela z 1985 roku).

42 W konsekwencji, przepisy rangi ustawy dotyczące nadzoru państwowego nad szkołami wyższymi ograniczyły się do unormowań o następującej treści: „Minister [...] realizuje politykę państwa w dziedzinie szkolnictwa wyższego, koordynuje w tym zakresie działalność szkół wyższych oraz nadzoruje i kontroluje podległe szkoły wyższe. Uprawnienia Ministra [...] w zakresie nadzoru i kontroli podległych szkół wyższych określają przepisy ustawowe”. Docelowo — art. 6 ust. 1 u.sz.w.1982.

${ }^{43}$ Pierwotnie był bowiem legitymowany do zgłaszania zastrzeżeń, a jeśli w tym zakresie nie dochodziło do uzgodnienia stanowisk, to minister (za zgodą prezydium RGNiSzW) podejmował „decyzję w sprawie treści statutu" (art. 7 ust. 1-4 pierwotnego brzmienia u.sz.w.n.1982). Z czasem — na mocy noweli z 1985 roku - minister uzyskał kompetencję do ustalania statutu wzorcowego oraz, docelowo, do zatwierdzania statutu danej szkoły wyższej ,po sprawdzeniu jego zgodności z prawem i zasadami określonymi w statucie wzorcowym" (docelowo - art. 9 ust. 1-6 u.sz.w.1982).

44 Por. pierwotne brzmienie art. 41 ust. 1-6 z art. 41 ust. 1-6 u.sz.w.1982 w wersji wynikającej noweli z 1985 roku. 
Jak już wskazywano, dopiero od dnia 27 września 1990 roku analizowany proces ewoluowania regulacji prawnych zapoczątkował etap monograficznego wyodrębnienia rozdziału o nadzorze ${ }^{45}$ (aczkolwiek w stanie prawnym obowiązującym od, co do zasady, dnia 1 października 2018 roku wyeksponowano poszerzenie spektrum zainteresowań rozdziału o nadzorczym przeznaczeniu ${ }^{46}$ ). Doszły do tego innowacje o stricte merytorycznym charakterze. W art. 31 ust. 2 u.sz.w.1990 wprowadzono bowiem termin (miesięczny) na uchylenie uchwały senatu lub decyzji rektora ${ }^{47}$. Z drugiej jednak strony przepisy u.sz.w.1990 kończą praktykę normatywną — notabene dość krótką — wymagającą od ingerencji w działalność szkół wyższych umocowania w przepisach rangi ustawy (art. 7).

Istotne - dla tytułowych antecedencji — ustalenie wynikające $\mathrm{z}$ analizy przepisów trzech ustaw (u.sz.w.1990, P.sz.w. i P.sz.w.n.) utrzymujących monograficzne zainteresowanie materią nadzorczą ${ }^{48}$ przedstawia się zaś następująco:

Daje się w tym względzie zauważyć tendencję, którą można nazwać malejącą. [...] jeżeli już ustawodawca zauważał w kontekście analizowanych aktów nadzoru problematykę form działania, to albo (od tego zaczęto) używał określeń wskazujących na to, że uznaje te formy działania za decyzje administracyjne (zob. także ww. art. 31 ust. 2 u.sz.w.1990), albo — poprzez art. 36 ust. 1a P.sz.w. [...] do obecnie obowiązującego art. 427 ust. 3 P.sz.w.n. — preferuje poprzestawanie na pośrednim nawiązywaniu do formy decyzji administracyjnej (co ważne, już nie dla potrzeb postępowania w sprawie wydania takiego aktu nadzoru, lecz z punktu widzenia trybu jego późniejszego zaskarżania do sądu administracyjnego $)^{49}$.

Warto też zauważyć, że w płaszczyźnie ad personam ustawodawca — począwszy od u.sz.w.1990 — zastrzega do wyłącznej gestii właściwego organu uczelni wybór rektora (z wyjątkiem pierwszego rektora nowo utworzonej uczelni publicznej, wtedy - państwowej $^{50}$. Co ważne, co do zasady jego odwołanie też pozostaje

45 Rozdział $1 \mathrm{w}$ dziale II — Nadzór nad uczelniami państwowymi.

46 O ile bowiem w rozdziale 3 działu I P.sz.w. chodziło jeszcze o Nadzór nad uczelniami, o tyle dział XIII P.sz.w.n. zatytułowano już Nadzór nad systemem szkolnictwa wyższego i nauki.

$47 \mathrm{~W}$ art. 36 ust. 1 P.sz.w. wprowadzono w tym zakresie dwie zmiany: wydłużono termin na zastosowanie tej ingerencji nadzorczej do dwóch miesięcy oraz wprowadzono sankcję stwierdzenia nieważności - a więc działającą ze skutkiem ex tunc. Na temat unormowania tej instytucji w P.sz.w.n. zob. pkt 4.

48 Co się zaś tyczy unormowań dotyczących statutów uczelni publicznych, to — od u.sz.w.1990 - ustawodawca zastrzega ich uchwalanie dla senatu (z wyjątkiem ministerialnej kompetencji do nadania pierwszego statutu nowo utworzonej uczelni), zob. art. 11-14 u.sz.w.1990; art. 19 ust. 3 i art. 56 P.sz.w.; art. 28 ust. 1, art. 34 ust. 2 i art. 35 ust. 8 P.sz.w.n. Wątek rektorski (rozpatrywany w perspektywie nadzorczej) powróci w dalszej części analizy.

49 P. Lisowski, Decyzje administracyjne w sprawach ustrojowych (decyzje nadzorcze) tekst oddany do publikacji przygotowywanej pod egidą XXVI Zjazdu Katedr Prawa i Postępowania Administracyjnego Kierunki rozwoju jurysdykcji administracyjnej (w procesie wydawniczym; fragment ze s. 5).

50 Art. 60 i art. 10 ust. 4 u.sz.w.1990; art. 72 i art. 19 ust. 2 P.sz.w.; art. 24 ust. $2-4$ i ust. 9 pkt 1 P.sz.w.n. 
sprawą wewnętrzną danej szkoły wyższej ${ }^{51}$, z tym że pod rządami P.sz.w. — i to w ramach przepisów o nadzorze ${ }^{52}$ - ustanowiono kompetencję do odwoływania rektora uczelni publicznej przez ministra („,W przypadku rażącego naruszenia prawa przez rektora, minister właściwy do spraw szkolnictwa wyższego może odwołać rektora [...] i wyznaczyć termin do powołania rektora w trybie określonym w statucie uczelni”) ${ }^{53}$. Ten trend utrzymuje art. 432 ust. 5 P.sz.w.n., „Jeżeli rektor rażąco lub uporczywie narusza przepisy prawa, minister może go odwołać, po zasięgnięciu opinii RGNiSW oraz właściwej konferencji, o której mowa w art. 329 ust. 1 pkt 2-4. Opinie są przedstawiane w terminie 30 dni od dnia doręczenia wniosku o ich wydanie. W przypadku bezskutecznego upływu tego terminu, wymóg zasięgnięcia opinii uważa się za spełniony". Z kolei w art. 432 ust. 1 P.sz.w.n. podtrzymano umocowanie ministra do wystapienia wnioskiem o odwołanie rektora do właściwego organu danej uczelni ${ }^{54}$, zastrzegając zarazem, że ,[d]o czasu rozpatrzenia wniosku o odwołanie rektora minister może zawiesić go w pełnieniu funkcji” ${ }^{\prime 5}$.

\section{Konsekwencje braku klauzuli generalnej gwarantującej sądową ochronę autonomii administracyjnej uczelni pu- blicznych — rozważania hic et nunc}

Aktualny stan normowania problematyki nadzoru nad szkołami wyższymi stanowi efekt wieloletnich procesów, nie zawsze konsekwentnych i wolnych od zagrożeń charakterystycznych dla patologii administracji publicznej. Co więcej, hic et nunc ewentualne braki w unormowaniu tej materii mogą uruchamiać relatywnie groźniejsze konsekwencje dla praktycznego wymiaru autonomii uczelni publicznych (a docelowo - dla sfery wolności akademickiej) ${ }^{56}$. Jest tak przede wszystkim dlatego, że notoryjny jest przecież poważny kryzys instytucji demokratycznego państwa prawnego w Polsce. Poza tym obecnie obowiązująca ustawa, choć utrzymuje większość z wypracowanych w tym względzie dobrych praktyk legislacyjnych, notuje kilka istotnych regresów w normatywizowaniu materii nadzorczej ${ }^{57}$. Nie jest też przełomowa w kwestii sądowej ochrony autonomii ad-

51 Art. 61 u.sz.w.1990; art. 78 P.sz.w.; art. 27 ust. 1-2 P.sz.w.n.

52 Takiej kompetencji nie przewidywała u.sz.w.1990.

53 Art. 38 ust. 5 P.sz.w.

54 Por. art. 432 ust. 1 P.sz.w.n. $z$ art. 38 ust. 1 P.sz.w.

55 Art. 432 ust. 3 P.sz.w.n. Zob. też art. 432 ust.2 P.sz.w.n. i art. 38 ust. 2-3 P.sz.w.

56 Co więcej, także dla sfery wolności obywatelskiej (społecznej). Takie są bowiem przecież również kojarzone z zakładami administracyjnymi (publicznymi) — zob. Z. Czarnik,. J. Połuszny, Zakład publiczny, [w:] System Prawa Administracyjnego. Podmioty administrujace, t. 6, red. R. Hauser, Z. Niewiadomski, A. Wróbel, Warszawa 2011, s. 452.

${ }^{57}$ Między innymi podtrzymuje (po P.sz.w.) stan niezaliczania tytułów do ingerencji nadzorczej do materii ustawowej; poza tym nie ogranicza „rozstrzygnięcia w sprawie stwierdzenia nieważności aktu" terminem (art. 427 ust. 3 P.sz.w.n.). 
ministracyjnej uczelni publicznych — nie wprowadza bowiem podmiotowo motywowanej klauzuli generalnej w tym zakresie ${ }^{58}$. Poprzestaje natomiast na utrwaleniu dającej się w ostatnim czasie zauważyć tendencji do odchodzenia od traktowania większości decyzji nadzorczych podejmowanych w ramach nadzoru państwowego nad uczelniami publicznymi jako decyzji administracyjnych. Istotne jest przy tym to, że zarówno w pierwotnej fazie (zakładającej traktowanie środków nadzoru ad meritum jako decyzji administracyjnych), jak i późniejszej (poprzestającej na wykorzystywaniu decyzyjnych konotacji do wyznaczenia trybu zaskarżania do sądu administracyjnego rozstrzygnięcia w sprawie stwierdzenia nieważności aktu organu uczelni) chodziło o zagwarantowanie sądowej ochrony przed ingerencją nadzorczą. Problem jednak w tym, że nadal ta materia nie doczekała się gwarancji w randze podmiotowo konstruowanej zasady. Analiza historyczna może prowadzić w tym kontekście do konkluzji w typie nihil novi. Nie ulega przy tym wątpliwości, że w wielu omawianych wyżej okresach autonomia administracyjna uczelni wraz z dopuszczalnością poddawania jej ochronie sądowej znajdowały się w zdecydowanie gorszym położeniu. Niemniej perspektywa drugiej dekady XXI wieku jako punktu odniesienia dla konstatowania wyraźnie się intensyfikujących w polskich realiach zagrożeń dla tej sfery konstytucyjnie gwarantowanej samodzielności w administrowaniu — nadaje konstatowaniu braku powyższej klauzuli nowego, niepokojącego wymiaru i znaczenia. Powyższy regres zastanawia tym bardziej, że inspirowany jest ad intra (a nie, jak to wcześniej bywało, ad extra).

Dobrze eksponuje to sfera nadzoru ad personam. Pod rządami P.sz.w. wprost bowiem nie przesądzono o zaskarżalności zarówno odwołania, jak i zawieszenia rektora $\mathrm{w}$ pełnieniu funkcji - w trybie nadzoru. Przepisy dotyczące tych aktów nadzoru (art. 38 ust. 5 art. 38 ust. 1-3), w przeciwieństwie do art. 36 ust. 1a P.sz.w. ${ }^{59}$, nie kwalifikowały tego rodzaju form działania administracji i nie zajmowały się ich zaskarżalnością. Związane z tym wątpliwości analizowała judykatura, opowiadając się za uznaniem tak wspomnianego zawieszenia ${ }^{60}$, jak i odwołania $^{61}$ za decyzje administracyjne (z konsekwencjami co do trybu zaskarżalności

58 Poza tym pogłębia - po P.sz.w. — tendencję do rozbudowywania i uszczegółowiania regulacji rangi ustawy. W stosunku do poprzedniej ustawy takie podejście konstatowano na przykład w T. Jędrzejewski, P. Rączka, Statut uczelni według przepisów ustawy Prawo o szkolnictwie wyższym, [w:] Podmioty administracji publicznej i prawne formy ich działania. Studia i materiaty z Konferencji Naukowej poświęconej Jubileuszowi 80-tych urodzin Profesora Eugeniusza Ochendowskiego. Toruń 15-16 listopada 2005 r., Toruń 2005, s. 254.

59 W brzmieniu ustalonym nowelą z dnia 11 lipca 2014 roku (Dz.U. z 2014 r. poz. 1198; dalej: nowela z 2014 roku); do dnia 30 września 2014 roku tę kwestię regulował art. 36 ust. 1 zd. drugie i trzecie pierwotnego brzmienia P.sz.w.

60 Na przykład postanowienie WSA w Warszawie z dnia 25 sierpnia 2011 roku (II SA/Wa 600/11, LEX nr 897199); postanowienie NSA z dnia 8 lutego 2012 roku (I OSK 2207/11, LEX nr 1126277).

61 Na przykład wyrok WSA w Warszawie z dnia 17 czerwca 2011 roku (II SA/Wa 40/11, LEX nr 993985); wyrok WSA w Warszawie z dnia 12 lutego 2013 roku (II SA/Wa 1600/12, LEX nr 1323779). 
tych decyzji nadzorczych). Co jednak ciekawe, orzeczenia optujące za poddaniem wymienionych aktów nadzoru bezpośredniej kontroli sądów administracyjnych używały argumentu, który nie wpisuje się ani w dominujący trend orzeczniczy, ani $\mathrm{w}$ dającą się zauważyć tendencję $\mathrm{w}$ ewoluowaniu analizowanych przepisów. Jak już wskazywałem, ustawodawca odchodzi od uznawania tych aktów nadzoru za decyzje administracyjne ${ }^{62}$. Co symptomatyczne, orzeczenia kwalifikujące te środki nadzoru ad personam jako decyzje nie znalazły potwierdzenia w stanie prawnym obowiązującym od 1 października 2018 roku. Tego rodzaju argumentacji judykatura nie wykorzystała też (jak dotychczas) w stosunku do art. 432 ust. 3 i 5 P.sz.w.n. Brakuje także podstaw prawnych do twierdzenia, że w tym zakresie powinien znaleźć zastosowanie mechanizm wskazywany w art. 427 ust. 3 P.sz.w.n. Ta sytuacja ewidentnie eksponuje ryzyko niewprowadzenia przez ustawodawcę klauzuli gwarantującej sądową ochronę autonomii administracyjnej uczelni publicznych, przekonując do kwalifikowania tego stanu jako zaniechanie prawodawcze ${ }^{63}$. W warunkach trendu sprzyjającego autorytarnym zachowaniom władzy publicznej w Polsce trudno uznać to za optymistyczną konstatację. Tym bardziej, że wpisuje się w szerszy kontekst zagrożeń i patologii administrowania, który dobrze ilustruje następująca refleksja: „Ograniczanie autonomii i niezależności poprzez kontrolowanie i uzależnianie [...] dokonuje się nie tylko bezpośrednio, ale i przez nominacje kadrowe czy uzależnienia finansowe (rozdział grantów czy funduszy, tworzenie scentralizowanych form ich rozdziału, promocja niektórych organizacji)"64. Autorytarne inklinacje obozu rządzącego dają zatem o sobie znać zarówno de facto, jak i de iure.

\section{Bibliografia}

Budnik A., Miruć A., Autonomia szkół wyższych w świetle przepisów ustawy - Prawo o szkolnictwie wyższym, [w:] Kryzys prawa administracyjnego? Inflacja prawa administracyjnego, t. 2, red. P.J. Suwaj, Warszawa 2012, s. 207-225.

Czarnik Z., Połuszny J., Zakład publiczny, [w:] System Prawa Administracyjnego. Podmioty administrujace, t. 6, red. R. Hauser, Z. Niewiadomski, A. Wróbel, Warszawa 2011, s. 415-500.

Janku Z., Publiczna szkoła wyższa - korporacja czy zakład administracyjny, [w:] Między tradycja a przyszłościa w nance prawa administracyjnego. Księga jubileuszowa dedykowana Profesorowi Janowi Bociowi, red. J. Supernat, Wrocław 2009, s. 234-242.

62 Na przykład wyrok NSA z dnia 2 grudnia 2010 roku (I OSK 1579/10, LEX nr 745091) dotyczący pierwotnego brzmienia art. 36 ust. 1 P.sz.w. — oraz wyrok NSA z dnia 21 marca 2019 roku (I OSK 1317/17, LEX nr 2650402) podjęty w stanie prawnym ukształtowanym nowelą z 2014 roku.

63 Eksponowaniu takiej konstatacji dodatkowo sprzyja fakt ponownego zauważania przez ustawodawcę korporacyjnych atrybutów uczelni (zob. art. 10 ust. 1 P.sz.w.n.). Powtórnie więc zyskują na znaczeniu korporacyjne konotacje szkół wyższych; więcej na ten temat na przykład E. Ochendowski, Pojęcie i charakter prawny publicznej szkoty wyższej, [w:] Nowe prawo o szkolnictwie wyższym a podmiotowość studenta, red. A. Szadok-Bratuń, Wrocław 2007, s. 34-35.

64 E. Łętowska, op. cit. 
Jędrzejewski T, Rączka P., Statut uczelni wedtug przepisów ustawy Prawo o szkolnictwie wyższym, [w:] Podmioty administracji publicznej i prawne formy ich działania. Studia i materiały z Konferencji Naukowej poświęconej Jubileuszowi 80-tych urodzin Profesora Eugeniusza Ochendowskiego. Toruń 15-16 listopada 2005 r., Toruń 2005, s. 249-264.

Konstytucje Rzeczypospolitej oraz komentarz do Konstytucji RP z 1997 r., red. J. Boć, Wrocław 1998.

Lisowski P., Decyzje administracyjne w sprawach ustrojowych (decyzje nadzorcze) — tekst oddany do publikacji przygotowywanej pod egidą XXVI Zjazdu Katedr Prawa i Postępowania Administracyjnego pt. Kierunki rozwoju jurysdykcji administracyjnej.

Lisowski P, Fenomen autonomii uczelni jako aksjomat administracji publicznej (prawa administracyjnego), [w:] Fenomen prawa administracyjnego. Księga Jubileuszowa Profesora Jana Zimmermanna, red. W. Jakimowicz, M. Krawczyk, I. Niżnik-Dobosz, Warszawa 2019, s. 576-591.

Lisowski P., Relacje strukturalne w polskim samorzadzie terytorialnym, Wrocław 2013.

Lisowski P., Zróżnicowanie samorządu terytorialnego a unitarność, [w:] Unitarny charakter państwa a samorzad terytorialny, red. M. Stec, K. Małysa-Sulińska, Warszawa 2019, s. 213-230.

Łętowska E., Państwo prawa na peryferiach Europy, https://publica.pl/teksty/letowska-panstwo-prawa-na-peryferiach-europy-61676.html (dostęp: 16.02.2021).

Masternak-Kubiak M., Autonomia szkót wyższych na gruncie Konstytucji RP, [w:] Nowe prawo o szkolnictwie wyższym a podmiotowość studenta, red. A. Szadok-Bratuń, Wrocław 2007, s. $13-20$.

Ochendowski E., Pojęcie i charakter prawny publicznej szkoły wyższej, [w:] Nowe prawo o szkolnictwie wyższym a podmiotowość studenta, red. A. Szadok-Bratuń, Wrocław 2007, s. 27-35. 